\title{
Effects of a plasma heating procedure for inactivating Ebola virus on common chemical pathology tests
}

\author{
YK Chong, WY Ng, Sammy PL Chen, Chloe M Mak*
}

\section{A B S T R A C T}

Objectives: The recent declaration of Ebola virus disease as epidemic by the World Health Organization indicates urgency for affected countries and their laboratories to evaluate and provide treatment to patients potentially infected by the Ebola virus. A heat inactivation procedure involving treating specimens at $60^{\circ} \mathrm{C}$ for 60 minutes has been suggested for inactivation of the Ebola virus. This study aimed at evaluating the effect of plasma heating on common biochemical tests.

Design: Comparative experimental study.

Setting: A regional chemical pathology laboratory in Hong Kong.

Methods: Forty consecutive plasma specimens for general chemistry analytes on Beckman Coulter AU5822 and another 40 plasma specimens for troponin I analysis on Access 2 Immunoassay System were obtained, anonymised, and divided into two aliquots. One aliquot was analysed directly and the other was analysed after heating at $60^{\circ} \mathrm{C}$ for 60 minutes.

Results: A total of 20 chemical pathology tests were evaluated. Nine tests (sodium, potassium, chloride, urea, creatinine, total calcium, phosphate, total protein, and glucose) were not significantly affected by the heat inactivation procedure and remained clinically interpretable. Results for magnesium (15\% mean increase), albumin (41\% mean increase), bilirubin ( $8 \%$ mean decrease), amylase $(27 \%$ mean proportional bias. However, all enzymes studied except amylase (alanine transaminase, aspartate transaminase, alkaline phosphatase, gammaglutamyltransferase, creatine kinase, and lactate dehydrogenase) were inactivated to a significant degree. Their Pearson $r$ or Spearman rho values ranged from no significant correlation $(P \geq 0.05)$ to 0.767 , and most normality was rejected.

Conclusion: Heat inactivation results in no significant change in electrolytes, glucose, and renal function tests, but causes a significant bias for many analytes. Recognition of the relationship between pre- and post-heat inactivation specimens allows clinical interpretation of affected values and contributes to patient care. For safety and diagnostic accuracy, we recommend use of a point-of-care device for blood gases, electrolytes, troponin, and liver and renal function tests within a class 2 or above biosafety cabinet with level 3 or above biosafety laboratory practice.

Hong Kong Med J 2015;21:201-7

DOI: 10.12809/hkmj144373

YK Chong, MB, BS

WY Ng, MB, ChB, PhD

SPL Chen, FRCPA, FHKAM (Pathology)

CM Mak *, FRCPA, FHKAM (Pathology)

Chemical Pathology Laboratory, Department of Pathology, Princess Margaret Hospital, Laichikok, Hong Kong

* Corresponding author: makm@ha.org.hk

New knowledge added by this study

- Heat inactivation results in no significant change in electrolytes, glucose, and renal function tests, but causes a significant bias for many analytes in routine biochemistry tests.

Implications for clinical practice or policy

- For the analytical methodologies tested, nine tests (sodium, potassium, chloride, urea, creatinine, total calcium, phosphate, total protein, and glucose) were not significantly affected.

- Magnesium, albumin, bilirubin, amylase, and troponin I were still interpretable using regression estimation with a linear proportional bias.

- However, alanine transaminase, aspartate transaminase, alkaline phosphatase, gamma-glutamyltransferase, creatine kinase, and lactate dehydrogenase were inactivated to a significant degree with rejected normality and are not useful clinically.

- When a patient suspected of having Ebola virus disease cannot be managed in a facility with comprehensive containment facilities, a heat inactivation procedure can be applied to allow analysis of the specimens with acceptable risk, when used in concert with appropriate precautions, and still yield some clinically useful results. 


\section{常見化學病理學測試中把血漿加熱作消滅埃博拉 病毒的效果}

\author{
張耀君、吳煒欣、陳栢林、麥苗
}

目的：世界衛生組織最近發出的聲明中指出，埃博拉（又稱伊波拉） 病毒的爆發顯示受影響國家和他們的實驗室作評估和治療感染者的迫 切性。有建議使用攝氏60度加熱60分鐘來消滅埃博拉病毒。本研究旨 在評估常見生化學測試中把血漿加熱的效果。

設計：對比試驗研究。

安排：香港一間區域醫院的化學病理實驗室。

方法：使用Beckman Coulter AU5822把連續40個進行一般化學分析 的血漿樣本, 並使用Access 2 Immunoassay System把另外連續40個 作肌䤮蛋白I分析的血漿樣本。本測試分別把這些樣本除名及分成兩等 份。把其中一份直接分析其化學結果, 另一份則在攝氏60度加熱60分 鐘後才進行分析。

結果：共進行了 20 個化學病理學測試。其中9項測試（鈵、鉀、氯 尿素、肌酸酐、總鉟、磷酸鹽、總蛋白和葡萄糖）沒有顯著受到熱滅 活過程影響, 並能維持臨床可測量的狀況。另外5種成分採用回歸估 計與比例偏差仍然能維持可測量的狀況：鎂（平均增加 15\%)、白蛋 白 (平均增加 $41 \%$ ) 、膽紅素（平均減少 $8 \%$ ）、澱粉酶（平均減少 $27 \%$ ）和肌銔蛋白I（平均減少 $70 \%$ ）。然而, 除了澱粉酶（丙氨酸 轉氨酶、天冬氨酸轉氨酶、鹵性磷酸酶、 $\gamma$-谷氨酰基轉移酶、肌酸激 酶、乳酸脱氫酶）外，所有酶均顯著失活; 其皮爾遜或斯皮爾曼rho值 介乎沒有顯著相關性（ $\mathrm{P} \geq 0.05)$ 至 0.767 之間, 而大多數常態分佈均 被推翻。

結論：熱滅活對於電解質、葡萄糖和腎功能檢查的結果並無顯著變 化, 但卻導致許多分析物出現顯著偏差。了解及識別樣本經熱滅活前 後的表現有助正確理解臨床數據, 對患者護理有幫助。為達至安全和 準確的診斷, 我們建議在第二級或以上的生物安全櫃, 或者三級或以 上的生物安全實驗室內使用重點照護檢驗裝置以作血液氣體、電解 質、肌鉟蛋白，以及肝和腎功能測試。

\section{Introduction}

Since March 2014, there has been an outbreak of Ebola virus disease (EVD) in West Africa; the affected countries include Guinea, Liberia, Sierra Leone and, more recently, Nigeria. The cumulative number of confirmed EVD cases rose exponentially from May to June 2014. ${ }^{1}$ On 8 August 2014, the World Health Organization (WHO) declared the EVD outbreak a "Public Health Emergency of International Concern", indicating that EVD is no longer a distant and confined issue, but a proximate and real threat. ${ }^{2}$

The Ebola virus was first discovered in 1976. ${ }^{3,4}$ It can be transmitted through direct contact with blood, secretions, and other body fluids or tissues of infected animals or persons. . $^{3,4}$ The incubation period of EVD ranges from 2 to 21 days, ${ }^{5}$ and a case fatality rate of $90 \%$ has been reported. ${ }^{5}$

Chemical pathology laboratory investigations are among the most basic and common tests requested for patients, particularly when intensive care is required, as would be expected for patients with EVD who are critically ill. Standard, contact, and droplet precautions have been recommended for the management of hospitalised patients with suspected EVD. ${ }^{6}$ While EVD is not normally transmitted by aerosol, there is a concern that the Ebola virus can remain infectious in laboratory-generated aerosol. ${ }^{7-9}$ Hence, stringent guidelines for laboratory personnel with respect to handling of laboratory specimens containing Ebola virus have been published. ${ }^{10,11}$ The WHO suggested in its interim guideline that "activities such as micro-pipetting and centrifugation can mechanically generate fine aerosols that might pose a risk of transmission of infection through inhalation as well as the risk of direct exposure", and recommended that gown, gloves, eye-face protection, and particulate respirators such as the US National Institute for Occupational Safety and Health-certified N95 respirator should be used when laboratory personnel are performing activities such as aliquoting, centrifugation, and other procedures that may generate aerosol. ${ }^{10}$

Nowadays, most general chemistry tests are performed with analysers that aspirate specimens from primary blood collection tubes on which centrifugation has been performed. Flushing the instrumental parts with Triton X-100 (Dow Chemical Company, Midland [MI], US) or Clorox (Clorox, Oakland [CA], US) has been suggested for decontamination after analysis of specimens containing Ebola virus. However, such disinfection procedure may not achieve $100 \%$ inactivation of the virus and is likely to affect the chemical analysis. Therefore, general chemistry analysers are not suitable for analysing highly infectious specimens. Processing of these specimens without an adequate disinfection procedure will pose an occupational health hazard to laboratory workers. It has been suggested that specimens that potentially contain live Ebola virus should be processed in a class 2 biological safety cabinet following biosafety level 3 practices. ${ }^{6}$

With regard to inactivation of Ebola virus in blood specimens of patients, the heat inactivation procedure (incubation of serum or plasma specimens at $60^{\circ} \mathrm{C}$ for 60 minutes) has been reported to decrease viral titres in patients' specimens. ${ }^{12} \mathrm{~A}$ report on the effect of the same heat inactivation procedure in the Hitachi 917 (Roche Diagnostics, Basel, Switzerland) and Bayer ACS 180 (Bayer Diagnostics, New York, US) biochemistry analysers has demonstrated minimal change in concentrations of sodium, potassium, urea, creatinine, glucose, urate, total bilirubin, amylase, and C-reactive protein, but significant reductions in concentrations of troponin, bicarbonate, total protein, albumin, total calcium, phosphate, aspartate aminotransferase 
(AST), alanine aminotransferase (ALT), alkaline phosphatase (ALP), gamma-glutamyltransferase (GGT), and creatine kinase (CK). ${ }^{13}$ However, the report only stated the change in percentage, with no information provided for diagnostic utility (eg the correlation of the post-heat inactivation procedure result with the result obtained without the inactivation procedure, which would indicate retention of diagnostic information). ${ }^{13,14}$ Therefore, this study aimed to provide a statistical delineation of the heat inactivation procedure effects on more common general chemistry analytes using the AU5822 (Beckman Coulter Inc, Pasadena [CA], US) and troponin I using the Access 2 Immunoassay System (Beckman Coulter Inc).

\section{Methods}

Forty consecutive plasma specimens were obtained, anonymised, and divided into two aliquots. One aliquot of the specimens was analysed immediately, whereas the other aliquot was analysed after heat inactivation at $60^{\circ} \mathrm{C}$ for 60 minutes. In addition, as a pilot study, 20 specimens with elevated cardiac troponin I $(>0.04 \mathrm{ng} / \mathrm{mL}$, 99th percentile of the reference interval), together with 20 specimens with cardiac troponin I that were not elevated (below the 99th percentile) were analysed in the same manner. Common general chemistry tests-including sodium, potassium, chloride, urea, creatinine, glucose, total protein, albumin, total bilirubin, ALT, AST, ALP, GGT, amylase, total calcium, phosphate, magnesium, $\mathrm{CK}$, and lactate dehydrogenase (LDH)-were performed on the AU5822 analyser and the troponin I test was done on the Access 2 Immunoassay System. The methodologies for the analytes are listed in Table 1 to allow laboratory staff using different analysers, but with similar methodologies, to adopt the results from the present study.

The heat inactivation procedure was performed according to a WHO guideline. ${ }^{12}$ Briefly,

TABLE I. Methodologies employed for measurement of analytes

\begin{tabular}{|c|c|}
\hline Analyte & Methodology \\
\hline \multicolumn{2}{|c|}{ Renal function tests } \\
\hline Sodium & Ion-selective electrode \\
\hline Potassium & Ion-selective electrode \\
\hline Urea & Urease/glutamate dehydrogenase \\
\hline Creatinine & Enzymatic (creatininase, creatinase, sarcosine oxidase) \\
\hline \multicolumn{2}{|c|}{ Liver function tests } \\
\hline Total protein & Biuret reaction \\
\hline Albumin & Bromocresol green $(\mathrm{pH} 4.2)$ \\
\hline Total bilirubin & DPD (3,5-dichlorophenyldiazonium tetrafluoroborate)/caffeine \\
\hline ALP & IFCC (p-nitrophenyl phosphate/2-amino-2-methylpropanol) \\
\hline ALT & IFCC ( $\mathrm{LDH}$ coupled) \\
\hline AST & IFCC (malate dehydrogenase coupled) \\
\hline GGT & IFCC (L-glutamyl-3-carboxy-4-nitroanilide/glycylglycine) \\
\hline \multicolumn{2}{|l|}{ Bone profile } \\
\hline Calcium & o-cresolphthalein complexone \\
\hline Phosphate & Molybdate with surfactant \\
\hline \multicolumn{2}{|c|}{ Other relevant analytes } \\
\hline CK & IFCC (hexokinase/glucose-6-phosphate dehydrogenase coupled) \\
\hline Amylase & IFCC (4,6-ethylidine(G6)-p-nitrophenyl(G1)-alpha-D-maltoheptaoside) \\
\hline LDH & IFCC (lactate to pyruvate) \\
\hline Magnesium & Xylidyl blue (dye-binding) \\
\hline Chloride & Ion-selective electrode \\
\hline Glucose & Hexokinase/glucose-6-phosphate dehydrogenase \\
\hline Troponin I & Immunoassay (AccuTnl, Beckman Coulter Inc) \\
\hline
\end{tabular}

Abbreviations: $\mathrm{ALP}=$ alkaline phosphatase; $\mathrm{ALT}=$ alanine aminotransferase; $\mathrm{AST}=$ aspartate aminotransferase; $\mathrm{CK}=$ creatine kinase; DPD = dihydropyrimidine dehydrogenase; GGT = gamma-glutamyltransferase; IFCC = International Federation of Clinical Chemistry; $\mathrm{LDH}=$ lactate dehydrogenase 
separated plasma aliquots were heated at $60^{\circ} \mathrm{C}$ for 60 minutes in a water bath while sealed in Eppendorf Tubes (Hamburg, Germany). The post-treatment specimens were then mixed inside the sealed tubes, allowed to settle, and analysed in the same manner as the untreated specimens.

\section{Statistical analysis}

Statistical tests were performed by MedCalc version 12.5 (MedCalc Software bvba, Ostend, Belgium). The pre- and post-treatment results were analysed with regard to normality by the KolmogorovSmirnov test, proportional change by PassingBablok regression, constant bias by paired $t$ test, and maintenance of diagnostic value by Pearson correlation coefficient. When normality was not accepted by the Kolmogorov-Smirnov test, Wilcoxon test was used in place of paired $t$ test, and Spearman rho in place of Pearson correlation coefficient. The $\mathrm{P}$ value of correlation was calculated for each analyte, with the linear regression accepted if the $P$ value was $<0.05$, and linearity model accepted with the CUSUM (cumulative sum) test.

The effect of the heat inactivation procedure on an analyte was considered insignificant if the slope of the regression line was between 0.95 and 1.05 , the linearity was preserved, and the correlation coefficient/rank correlation was $\geq 0.9$. The constant bias was evaluated as to its statistical significance by paired $t$ test or Wilcoxon test, and by consideration of clinical interpretation by two chemical pathologists. The effect of heat inactivation was considered interpretable if, despite a proportion bias, the linearity was preserved, and correlation coefficient/ rank correlation was $\geq 0.9$. If an analyte did not fulfil the above two criteria, the post-treatment measurement result was considered to have lost the diagnostic values.

\section{Results}

A total of 20 chemical pathology tests were evaluated. Figure 1 shows the percentage change in concentrations of each analyte, and Table 2 shows the range of concentration, regression equation, and Pearson correlation coefficient of each analyte before and after heating. Among the analytes, nine tests (sodium, potassium, chloride, urea, creatinine, total calcium, phosphate, total protein, and glucose) were not significantly affected by the heat inactivation procedure and remained clinically interpretable.

Despite the proportional differences, analytical results for magnesium (15\% mean increase), albumin ( $41 \%$ mean increase), bilirubin ( $8 \%$ mean decrease), amylase (27\% mean decrease), and troponin I (76\% mean decrease) were still interpretable, as the preand post-heat inactivation procedure results for these analytes were found to have significant correlation $(\mathrm{P}<0.0001$ for the aforementioned analytes, with Pearson $r$ or Spearman rho $>0.9$ ). These results can be interpreted with estimation from the significant proportional bias using the regression equation.

All the enzymes except for amylase (ALP, ALT, AST, CK, GGT, and LDH) were inactivated to a significant degree by the heat inactivation procedure, such that the results were considered uninterpretable. The Pearson $r$ or Spearman rho values ranged from no significant correlation $(\mathrm{P} \geq 0.05)$ to 0.767 , and most normality was rejected. The effect of the heat inactivation procedure on the analytes that were considered uninterpretable are shown in Figure 2.

\section{Discussion}

The need for more stringent statistical considerations in the evaluation of disinfection procedures such as the heat inactivation procedure in the present

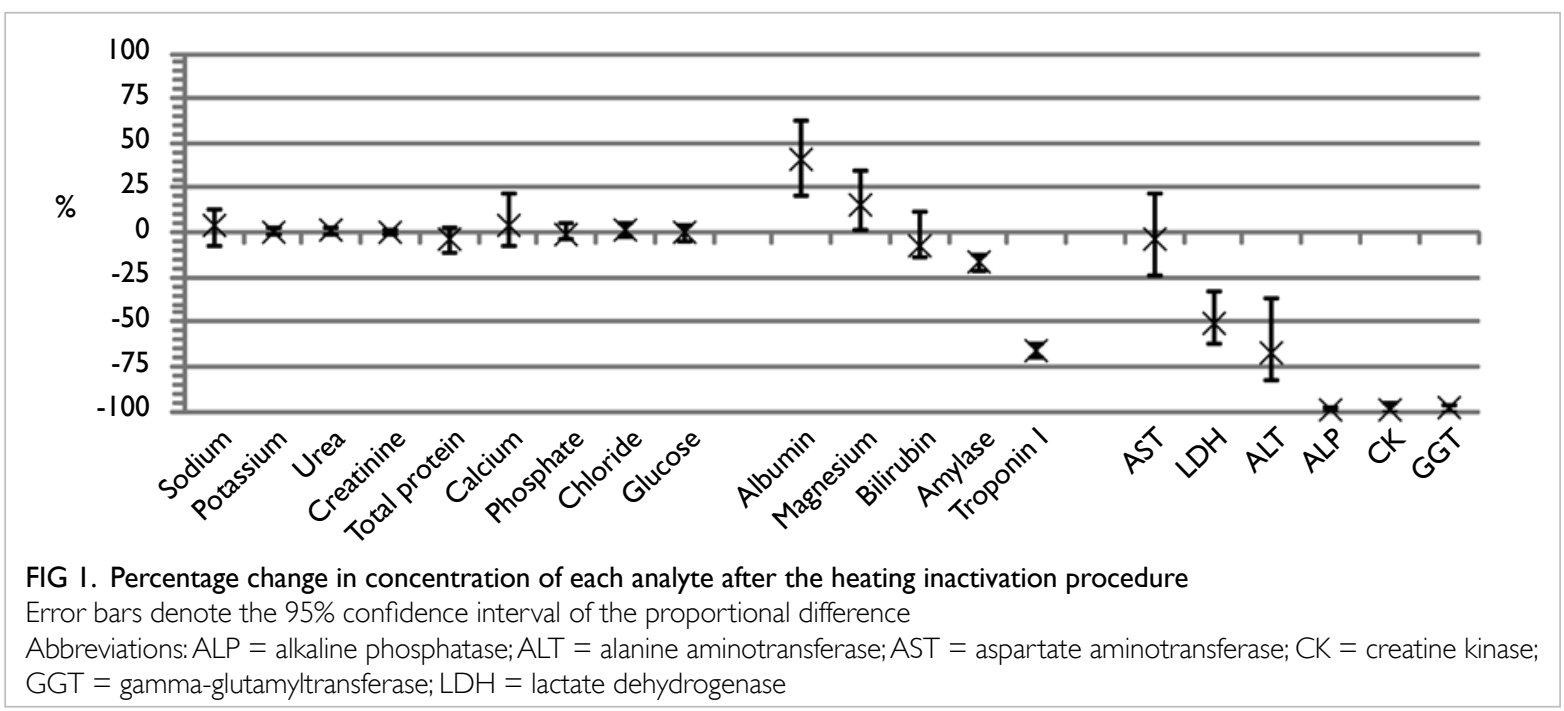


TABLE 2. Results before and after heat treatment of analytes

\begin{tabular}{|c|c|c|c|c|c|c|c|}
\hline Analyte & $\begin{array}{l}\text { Sample } \\
\text { size }\end{array}$ & $\begin{array}{l}\text { Range (median) } \\
\text { of untreated }\end{array}$ & $\begin{array}{c}\text { Range (median) } \\
\text { of post- } \\
\text { deactivation }\end{array}$ & $\begin{array}{c}\text { Regression } \\
\text { equation (y: post- } \\
\text { deactivation; } x \text { : } \\
\text { untreated) }\end{array}$ & $\begin{array}{c}\text { Pearson } \\
r\end{array}$ & Unit & Effect of HIP \\
\hline Sodium & 40 & $128-151(141)$ & $126-150(141)$ & $y=1.035 x-4.8^{*}$ & 0.964 & $\mathrm{mmol} / \mathrm{L}$ & No significant effect post-HIP \\
\hline Potassium & 40 & $3.4-6.2(4.3)$ & $3.4-6.2(4.3)$ & $y=1.000 x-0.03$ & 0.998 & $\mathrm{mmol} / \mathrm{L}$ & No significant effect post-HIP \\
\hline Urea & 38 & $2.2-45.8(6.1)$ & $2.2-47(6.2)$ & $y=1.008 x+0.03$ & $0.992 \dagger$ & $\mathrm{mmol} / \mathrm{L}$ & No significant effect post-HIP \\
\hline Creatinine & 38 & 37-1112 (84) & 50-1126 (88) & $y=1.005 x+4.2$ & $0.995 \dagger$ & $\mu \mathrm{mol} / \mathrm{L}$ & No significant effect post-HIP \\
\hline Total protein & 38 & $49-83(70)$ & $48-82(71)$ & $y=0.966 x+1.8$ & 0.986 & $g / L$ & No significant effect post-HIP \\
\hline Albumin & 39 & $25-50(42)$ & 33-72 (52) & $y=1.407 x-5.8$ & 0.937 & $g / L$ & Significant increase (41\%) post-HIP \\
\hline Bilirubin & 39 & $4-18(10)$ & $7-44(14)$ & $y=0.922 x+3.9$ & $0.907 \dagger$ & $\mu \mathrm{mol} / \mathrm{L}$ & Significant decrease (8\%) post-HIP \\
\hline Alkaline phosphatase & 39 & $43-280(74)$ & $0-6(1)$ & NS & NS & $\mathrm{U} / \mathrm{L}$ & Result not interpretable post-HIP \\
\hline Alanine transaminase & 38 & $6-118(17)$ & $1-21(6)$ & $y=0.321 x-0.3$ & $0.531 \dagger$ & $\mathrm{U} / \mathrm{L}$ & Result not interpretable post-HIP \\
\hline Aspartate transaminase & 35 & $9-243(21)$ & $13-185(24)$ & $y=0.958 x+2.1$ & $0.767 \dagger$ & $\mathrm{U} / \mathrm{L}$ & Result not interpretable post-HIP \\
\hline$\gamma$-Glutamyltransferase & 36 & $10-287(24)$ & $0-11(1)$ & NS & NS & $\mathrm{U} / \mathrm{L}$ & Result not interpretable post-HIP \\
\hline Calcium & 38 & $1.81-2.5(2.28)$ & $4-2.59(2.23)$ & $y=1.038 x-0.127$ & 0.930 & $\mathrm{mmol} / \mathrm{L}$ & No significant eff \\
\hline Phosphate & 38 & $0.45-2.65(1.03)$ & $0.48-2.66(1.07)$ & $y=0.991 x+0.054$ & 0.982 & $\mathrm{mmol} / \mathrm{L}$ & No significant effect post-HIP \\
\hline Creatine kinase & 39 & $15-6871(77)$ & $0-73(6)$ & NS & NS & $\mathrm{U} / \mathrm{L}$ & Result not interpretable post-HIP \\
\hline Amylase & 36 & $43-649(82)$ & $28-577(58)$ & $y=0.830 x-5.8$ & $0.986 \dagger$ & $\mathrm{U} / \mathrm{L}$ & Significant decrease (27\%) post-HIP \\
\hline Lactate dehydrogenase & 38 & 124-482 (189) & $5-205(82)$ & $y=0.488 x-7.6$ & 0.732 & $\mathrm{U} / \mathrm{L}$ & Result not interpretable post-HIP \\
\hline Magnesium & 39 & $0.53-1.06(0.88)$ & $0.61-1.16(0.98)$ & $y=1.148 x-0.02$ & 0.924 & $\mathrm{mmol} / \mathrm{L}$ & Significant increase (15\%) post-HIP \\
\hline Chloride & 40 & $91-116(106)$ & $90-115(106)$ & $y=1.014 x-1.3^{\star}$ & 0.989 & $\mathrm{mmol} / \mathrm{L}$ & No significant effect post-HIP \\
\hline Glucose & 39 & $3.5-15.5(5.4)$ & $3.9-16.1(6.1)$ & $y=0.996 x+0.49$ & 0.994 & $\mathrm{mmol} / \mathrm{L}$ & No significant effect post-HIP \\
\hline Troponin I & 40 & $0-154.61(0.21)$ & $0-46.88(0.06)$ & $y=0.340 x-0.001$ & $0.975 \dagger$ & $\mathrm{ng} / \mathrm{mL}$ & Significant decrease (76\%) post-HIP \\
\hline
\end{tabular}

Abbreviations: HIP = heat inactivation procedure; NS = not significant

* The systematic difference (intercept) for this analyte was not statistically different from zero

+ Normality rejected by Kolmogorov-Smirnov test, hence Spearman rho rather than Pearson $r$ was calculated

study is evident. For example, the effect of the heat leads to aerosolisation, ${ }^{10,11}$ the use of gel separator inactivation procedure on AST was quoted to have tubes allows the heat inactivation procedure a mean reduction of $26 \%$ in one of the reports. ${ }^{13}$ An to be performed without micro-pipetting after even lower average reduction of enzymatic activity centrifugation. As gel separator tubes have previously (4.2\%) was found in the present study although, been reported to cause analytical interference in the despite the low reduction, diagnostic information analysis of biochemical analytes such as therapeutic was significantly destroyed (Spearman rho rank- drugs and steroid hormones, ${ }^{15,16}$ for hospitals that order coefficient was only 0.767 ) after the heat do not use gel separator tubes, verification of assay inactivation procedure. In addition, consideration performance with gel separator tubes is necessary, should be taken in interpretation of the clinical although in the experience of the authors, the effect usefulness of post-heating results as some effects may of gel separator tubes is usually minimal among be statistically significant but clinically insignificant general chemistry analytes.

in certain pathological conditions.

Our assays of total protein, total calcium, and phosphate showed no significant difference despite more adverse effects reported by Bhagat et al. ${ }^{13}$ This may be due to differences in analytical assays. Therefore, local laboratories should evaluate their assays.

It must be noted that the heat inactivation procedure is only one of the many facets of safe laboratory practice involving highly infectious materials. As centrifugation and micro-pipetting

Apart from general chemistry analytes, another panel of tests most commonly employed in the management of patients is blood gas analysis. It is, however, impossible to inactivate blood gas specimens using heat treatment as such treatment would invariably affect the acid-base, and the partial pressure of oxygen and carbon dioxide in blood, rendering the specimen unsuitable for analysis. Disinfection of routine blood gas analysers after the processing of infected specimens is also problematic; the glass electrode and membranes used for blood 

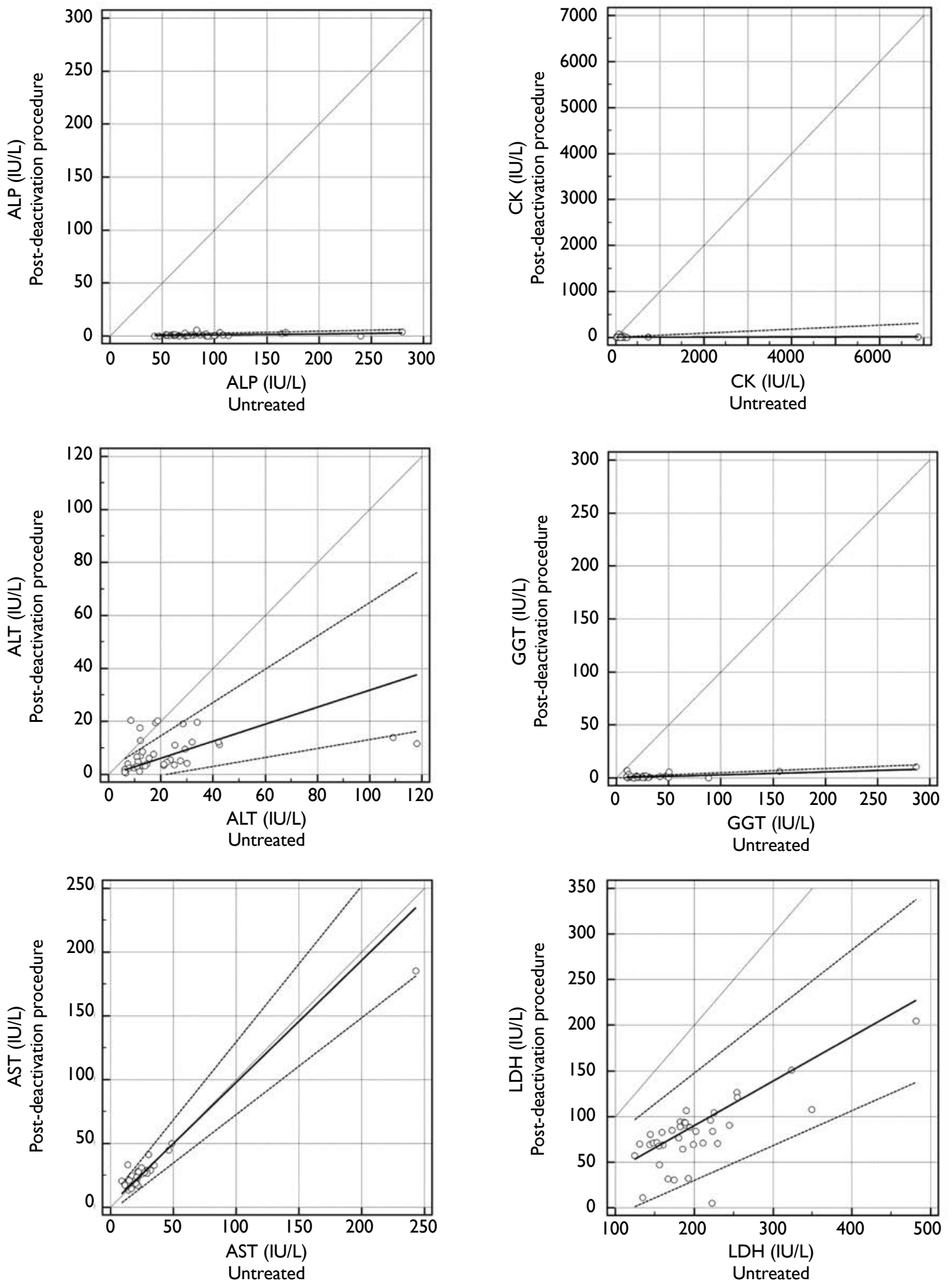

FIG 2. The effect of heat treatment on analytes that are incompatible with heat treatment

The regression lines (by Passing-Bablok regression) are shown in bold with $95 \%$ confidence intervals shown in broken lines Abbreviations: $\mathrm{ALP}=$ alkaline phosphatase; $\mathrm{ALT}=$ alanine aminotransferase; $\mathrm{AST}=$ aspartate aminotransferase; $\mathrm{CK}=\mathrm{creatine}$ kinase; GGT = gamma-glutamyltransferase; LDH = lactate dehydrogenase 
gas analysis are often not compatible with the high active chlorine content of bleach or the presence of surfactants in buffers used for disinfection purposes.

For blood gas analysis, the use of point-of-care analysers such as the i-STAT (Abbott Laboratories, Chicago [IL], US), whereby the test cartridge on which a blood specimen is applied is only connected to the analyser via electrical contacts, is seen as a viable alternative by the authors, as the test cartridge is single-use, can be disposed of safely, and the analyser can be cleaned and disinfected because of the vulnerable glass electrode, and the membranes on Clark- or Severinghaus-type electrodes (used for measurement of oxygen and carbon dioxide tensions) are not situated on the analyser properly.

Lastly, rather than performing the inactivation procedure in the laboratory, another option for analysis is the use of point-of-care analysers in an appropriate enclosure. Blood gas, electrolytes, and renal and liver function tests can all be performed in modern point-of-care analysers. In concordance with guidelines, it is recommended that the pointof-care analyser should be housed within a class 2 or above biosafety cabinet in a level 3 or above biosafety laboratory operating with appropriate precautions. ${ }^{11}$

\section{Conclusion}

We have presented the effect of the heat inactivation procedure on common biochemistry analytes, with statistical procedures applied to determine the diagnostic utility of the analyte concentrations. This serves to aid clinicians and laboratory staff in managing suspected and confirmed patients with EVD.

\section{Acknowledgements}

The authors would like to acknowledge Mr Kelvin Yu, Ms Kitty Soo, and Mr Philip Chiu for their kind assistance in performing the tests, and Ms Alision Lam for her kind assistance in the preparation of this manuscript.

\section{References}

1. World Health Organization. Disease Outbreak News (DONs) 2014 [12/8/2014]. Available from: http://www. who.int/csr/don/2014_08_11_ebola/en/. Accessed 12 Aug 2014.

2. IHR Emergency Committee Members and Advisers. WHO Statement on the Meeting of the International
Health Regulations Emergency Committee Regarding the 2014 Ebola Outbreak in West Africa 2014 [12/8/2014]. Available from: http://www.who.int/mediacentre/news/ statements/2014/ebola-20140808/en/. Accessed 12 Aug 2014.

3. Leroy EM, Kumulungui B, Pourrut X, et al. Fruit bats as reservoirs of Ebola virus. Nature 2005;438:575-6.

4. Wilson JA, Hevey M, Bakken R, et al. Epitopes involved in antibody-mediated protection from Ebola virus. Science 2000;287:1664-6.

5. Feldmann H, Geisbert TW. Ebola haemorrhagic fever. Lancet 2011;377:849-62.

6. Kortepeter MG, Martin JW, Rusnak JM, et al. Managing potential laboratory exposure to Ebola virus by using a patient biocontainment care unit. Emerg Infect Dis 2008;14:881-7.

7. Jaax N, Jahrling P, Geisbert T, et al. Transmission of Ebola virus (Zaire strain) to uninfected control monkeys in a biocontainment laboratory. Lancet 1995;346:1669-71.

8. Leffel EK, Reed DS. Marburg and Ebola viruses as aerosol threats. Biosecur Bioterror 2004;2:186-91.

9. Sewell DL. Laboratory-associated infections and biosafety. Clin Microbiol Rev 1995;8:389-405.

10. Interim infection prevention and control guidance for care of patients with suspected or confirmed Filovirus haemorrhagic fever in health-care settings, with focus on Ebola 2014. Available from: http://www.who.int/csr/ resources/who-ipc-guidance-ebolafinal-09082014.pdf. Accessed 12 Aug 2014.

11. Interim guidance for specimen collection, transport, testing, and submission for patients with suspected infection with Ebola virus disease 2014 [12/8/2014]. Available from: http:// www.cdc.gov/vhf/ebola/hcp/interim-guidance-specimencollection-submission-patients-suspected-infection-ebola. html. Accessed 12 Aug 2014.

12. WHO recommended guidelines for epidemic preparedness and response: Ebola haemorrhagic fever (EHF). Geneva: World Health Organization; 1997.

13. Bhagat CI, Lewer M, Prins A, Beilby J. Effects of heating plasma at 56 degrees $C$ for $30 \mathrm{~min}$ and at 60 degrees $C$ for $60 \mathrm{~min}$ on routine biochemistry analytes. Ann Clin Biochem 2000;37:802-4.

14. Hersberger M, Nusbaumer C, Scholer A, Knöpfli V, von Eckardstein A. Influence of practicable virus inactivation procedures on tests for frequently measured analytes in plasma. Clin Chem 2004;50:944-6.

15. Ferry JD, Collins S, Sykes E. Effect of serum volume and time of exposure to gel barrier tubes on results for progesterone by Roche Diagnostics Elecsys 2010. Clin Chem 1999;45:1574-5.

16. Bush V, Blennerhasset J, Wells A, Dasgupta A. Stability of therapeutic drugs in serum collected in vacutainer serum separator tubes containing a new gel (SST II). Ther Drug Monit 2001;23:259-62. 